\title{
Self-Reported Gum Bleeding in COVID-19 Patients: A Questionnaire- Based Study
}

\section{Rahaf Manzalawi, ${ }^{A}$ Khulud Alhamamey, ${ }^{A}$ Mohamed Roshdy Abdelrasoul ${ }^{B}$}

ADentistry Program, Batterjee Medical College, Jeddah, Kingdom of Saudi Arabia.

BPeriodontology Division, Dentistry Program, Batterjee Medical College, Jeddah, Kingdom of Saudi Arabia.

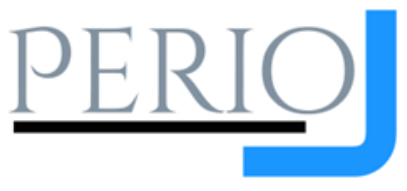

\begin{abstract}
$\underline{\text { Abstract }}$
Background: Coronavirus disease 2019 (COVID-19) has affected a huge number of people around the world. It has increased worldwide mortality and morbidity and is accompanied by different signs and symptoms. Some researchers have linked oral manifestations as introductory signs for COVID-19, such as vesiculobullous lesions, non-specific stomatitis, and oral ulcers. The oral cavity has been perceived as a potential reservoir for asymptomatic COVID-19 infection, specifically the salivary glands and the oral mucosa. This study builds on a previous case report by the authors on COVID-19 associated gingival bleeding in an attempt to investigate the generalization of this relation. Methods: A cross-sectional survey based on a structured, pretested, and validated questionnaire that was adapted and modified by the authors was carried out electronically for a minimal sample size of patients that was calculated for this study beforehand. This study was approved by the Batterjee Medical College ethical committee and data collection followed a structured criteria and a clear work plan based on the established inclusion criteria. Results: The questionnaire had a high response rate of 315 participants. 63.2\% ( $\mathrm{n}=199)$ reported gum bleeding during virus infection time $-25.6 \%(\mathrm{n}=51)$ of whom reported that this symptom was present prior to COVID-19 infection. 88.9\% $(n=177)$ of participants reported only mild bleeding. Gingival bleeding was more prevalent among females 63.8\% ( $\mathrm{n}=127)$ compared to males $36.2 \%(\mathrm{n}=72)$ (odds ratio: 0.859 [95\% CI, o.530 to 1.394]). Conclusion: Gingival bleeding may be considered as one of the signs of COVID-19 and is a prevalent symptom as reported by infected patients. However, a larger sample size and investigation of hospitalized moderate and severe cases of the disease would help elucidate the actual association.
\end{abstract}

Keywords: COVID-19; gingival bleeding; dental; infectious diseases; periodontal disease

\section{Introduction}

The first instance of infection with the severe acute respiratory syndrome coronavirus 2 (SARS-CoV-2) was reported in the city of Wuhan, China in December 2019 resulting in the novel coronavirus disease 2019 (COVID-19). ${ }^{1}$ The World Health Organization (WHO) announced COVID-19 a public health emergency of international concern in January 2020. Ever since, the COVID-19 pandemic has infected a large number of individuals worldwide. The disease has clearly increased mortality and morbidity around the world, and it has a variety of symptoms and impacts. Some of the symptoms associated with COVID-19 include fever, dry cough, headaches, weakness, and others.2,3 Moreover, age, gender, ethnicity, and comorbidities are risk factors that increase the risk of SARS-CoV-2 infection complications and mortality. ${ }^{4}$

It has been reported that some COVID-19 patients, despite being negative for the viral nucleic acid, often still present with a high level of inflammation, indicating that inflammation is a major feature in COVID-19 patients. Furthermore, excessive inflammation, a depressed immune system, and an active cytokine storm substantially contribute to the pathogenesis of COVID19.5 In the early stages of coronavirus infection, dendritic cells and epithelial cells 
are activated and express a cluster of proinflammatory cytokines and chemokines including interleukin (IL)-1 $\beta$, IL-2, IL-6, IL8 , both interferon (IFN)- $\alpha / \beta$, and tumor necrosis factor (TNF) contributing to the development of disease. 6,7

The oral cavity has been perceived as a potential reservoir for asymptomatic COVID-19 infection, specifically the salivary glands and the oral mucosa, owing to the high expression of angiotensin-converting enzyme 2 (ACE2) receptors in minor salivary glands, which is also the functional receptor of SARS-CoV. ${ }^{8}$ In fact, the expression of ACE2 receptors in minor salivary glands is higher than that in the lungs. SARS-CoV RNA can be detected in saliva before lung lesions appear, explaining the presence of asymptomatic infections. The salivary gland could be a major source of SARS-CoV in saliva. The positivity rate of COVID-19 in patients' saliva can reach $91.7 \%$, attributing to the potential infectivity of saliva. ${ }^{8}$

Some researchers have linked oral manifestations to COVID-19 infections, such as vesiculobullous lesions, non-specific stomatitis, and oral ulcers.9,10 Oral manifestations have also been associated with COVID-19 as an initial symptom in several studies. Carreras-Presas et al. for example, described vesiculobullous lesions in the oral cavities of SARS-CoV-2 infected patients. ${ }^{11}$

This study builds on a previous case report by the authors on COVID-19 associated gingival bleeding, where there were anecdotal reports of unprecedented profuse gingival bleeding that was not present before active signs of COVID-19 developed, specifically preceding or alongside fever. ${ }^{12}$ Doubts about the relationship between COVID-19 and dental health exist however, as patients can be affected by oral manifestations either as a typical pattern resulting from the direct infection, or these lesions can result from the systemic deterioration caused by the infection, or as adverse reactions from treatment. ${ }^{13}$

It has recently been established that periodontitis was associated with a higher risk of ICU admission, assisted ventilation, COVID-19 death, and elevated blood levels of biomarkers linked to worse disease outcomes.14 Asymptomatic COVID-19 patients may present for emergency dental treatment and are expected to have saliva a confirmed source of infection contaminated with the virus. Moreover, the conjunctival mucosa and upper respiratory tract are connected by the nasolacrimal duct and share ACE2 on their cell membrane. 15 This exposes dental healthcare personnel to the risk of infection via direct exposure of the conjunctiva to droplets from patients during dental treatment. ${ }^{16}$

The presence of initial or inaugural signs for COVID-19 in the oral cavity may bring to the attention of dental practitioners the suspicion of current or imminent infection in otherwise asymptomatic carriers or patients. Hence, the aim of this questionnaire-based study was to further investigate direct or indirect associations of introductory or concurrent gingival bleeding with COVID-19.

\section{Materials and Methods}

This study was approved by the Batterjee Medical College ethical committee (UBRES-2020-0049) and data collection followed a structured criteria and a clear work plan based on the established inclusion criteria.

A cross-sectional survey based on a structured, pre-tested and validated questionnaire that was adapted by the authors, and was modified from previous studies to suit the local population was carried out electronically to assess gingival bleeding association with COVID-19 in positive patients. The purpose of the study was explained in the covering letter of the questionnaire, which contained eight questions. Participating subjects and patients signed an informed consent.

The sample size was calculated based on the results of Chen et al., who reported a prevalence of sore throat in 17.4\% of COVID19 patients. ${ }^{17}$ Based on the results of Chen et al.'s study, the present study's sample consisted of 220 patients each with a confirmed diagnosis of COVID-19. Considering a possible loss of about $10 \%$ of patients, a total of 242 patients formed the final sample size to be recorded for the study 
according to the following equation: sample size $=\mathrm{Z} 1-\mathrm{a} / \mathrm{2}^{2} \mathrm{p}(1-\mathrm{p}) / \mathrm{d}^{2} . \mathrm{Z} 1-\mathrm{a} / 2=1.96$, where $\mathrm{p}=$ expected proportion in the population based on previous studies or pilot studies (17.4\%), and $\mathrm{d}=0.05$.

The subjects were selected using a convenient sampling method. Participants were eligible to be included if they: 1) were above 18 years old, 2) understood the Arabic or English language, and 3) currently are or were COVID-19 positive patients within the past six months, to allow for patients to recall the symptoms. Those who did not meet any of those criteria were excluded from the study. A positive COVID-19 infection was confirmed via the real-time reverse transcription polymerase chain reaction (rRT-PCR) test for the qualitative detection of nucleic acid from SARS-CoV-2 in upper respiratory specimens from nasopharyngeal or oropharyngeal swabs.

Statistical analyses were carried out using the SPSS software package (version 20.0). Descriptive measures presented included percentages and corresponding $95 \%$ confidence intervals (CIs). $\mathrm{P}<0.05$ was considered statistically significant. The association between gingival bleeding and COVID-19 infection was analyzed using logistic regression and data were reported as odds ratios (ORs) with 95\% CI.

\section{Results}

The response rate for the questionnaire was higher than the calculated minimum sample size, as 315 participants responded to the survey. The demographic data of the studied patients is depicted in Table 1 . The majority of the studied patients were females $(65.1 \%$; $\mathrm{n}=205$ ), and approximately half of the patients were young adults ranging between $18-30$ years of age $(49.5 \% ; n=156)$, with a gradual decrease in number in each age category up to the age of 60 years or more. The mean age of the studied patients was $33.4 \pm 10.7$ years. Furthermore, the breakdown of oral hygiene practices during the phase of infection revealed that nearly half of the patients (47.3\%; $n=149)$, practiced in accordance to the universal guidelines on proper tooth brushing of twice daily. The practice of flossing was reported among only $33 \%(n=104)$ of participants, while the remainder declined its use.
Table 1. Description of the studied patients according to demographic data

\begin{tabular}{|c|c|c|}
\hline & \multicolumn{2}{|c|}{$(n=315)$} \\
\hline & No. & $\%$ \\
\hline \multicolumn{3}{|l|}{ Q1. Sex } \\
\hline Male & 110 & 34.9 \\
\hline Female & 205 & 65.1 \\
\hline \multicolumn{3}{|l|}{ Q2. Age } \\
\hline $18-30$ & 156 & 49.5 \\
\hline $31-40$ & 89 & 28.3 \\
\hline $41-50$ & 46 & 14.6 \\
\hline $51-60$ & 18 & 5.7 \\
\hline $60+$ & 6 & 1.9 \\
\hline Mean \pm SD & \multicolumn{2}{|c|}{$33.4 \pm 10.7$} \\
\hline Median (Min-Max.) & \multicolumn{2}{|c|}{$31(18-65)$} \\
\hline \multicolumn{3}{|l|}{$\begin{array}{l}\text { Q3. How many times do you } \\
\text { brush your teeth daily? }\end{array}$} \\
\hline Once a day & 109 & 34.6 \\
\hline Twice a day & 149 & $47 \cdot 3$ \\
\hline Thrice a day & 41 & 13 \\
\hline Less than 3 times weekly & 12 & 3.8 \\
\hline I rarely brush my teeth. & 4 & 1.3 \\
\hline \multicolumn{3}{|l|}{ Q4. Do you use dental floss? } \\
\hline No & 211 & 67 \\
\hline Yes & 104 & 33 \\
\hline
\end{tabular}

SD: standard deviation

The descriptive statistics of the studied patients illustrating gum bleeding during the period of virus infection are presented in Table 2. It shows that nearly two-thirds of the studied patients (63.2\%; $\mathrm{n}=199$ ) reported that gum bleeding occurred during the period of virus infection, among them, $74.4 \% \quad(n=148)$ reported that this symptom was not present prior to contracting SARS-CoV-2 and was not a complaint of theirs prior to infection. A large percentage of the patients $(53.3 \%$; $n=106)$ reported that bleeding occurred spontaneously without provocation and among those who reported bleeding, 89.4\%, $(n=178)$ stated that it stopped shortly after and did not continue on its own. The majority of patients $(78.4 \% ; \mathrm{n}=156)$ reported that there was no specific time that bleeding occurred during the day, and most (88.9\%; $\mathrm{n}=177$ ) described the degree of bleeding as being mild. Finally, $47.7 \%$ of patients $(n=95)$ stated that bleeding discontinued postCOVID-19. 
Table 2. Description of the studied patients according to gingival bleeding during time of virus infection

\begin{tabular}{|c|c|c|}
\hline & No. & $\%$ \\
\hline $\begin{array}{l}\text { Q5. Did you have gum } \\
\text { bleeding during time of } \\
\text { virus infection? }\end{array}$ & \multicolumn{2}{|c|}{$(n=315)$} \\
\hline No & 116 & 36.8 \\
\hline Yes & 199 & 63.2 \\
\hline $\begin{array}{l}\text { Q6. If you answered yes, did } \\
\text { you suffer from bleeding } \\
\text { gums before getting } \\
\text { infected with COVID-19? }\end{array}$ & \multicolumn{2}{|c|}{$(n=199)$} \\
\hline No & 148 & 74.4 \\
\hline Yes & 51 & 25.6 \\
\hline $\begin{array}{l}\text { Q7. Is bleeding related to } \\
\text { the presence of provocation } \\
\text { factors? (for example: hot } \\
\text { food, hard food, tooth } \\
\text { brushing, etc.) }\end{array}$ & \multicolumn{2}{|c|}{$(n=199)$} \\
\hline No & 106 & 53.3 \\
\hline Yes & 93 & 46.7 \\
\hline $\begin{array}{l}\text { Q8. Does bleeding continue } \\
\text { on its own? }\end{array}$ & \multicolumn{2}{|c|}{$(n=199)$} \\
\hline No & 178 & 89.4 \\
\hline Yes & 21 & 10.6 \\
\hline $\begin{array}{l}\text { Q9. What is the time of day } \\
\text { that you usually suffer from } \\
\text { bleeding gums the most? }\end{array}$ & \multicolumn{2}{|c|}{$(n=199)$} \\
\hline After waking up & 23 & 11.6 \\
\hline In the morning & 9 & 4.5 \\
\hline In the evening & 6 & 3.0 \\
\hline Before sleeping & 5 & 2.5 \\
\hline Not related to specific time & 156 & 78.4 \\
\hline $\begin{array}{l}\text { Q10.What is your } \\
\text { assessment of the amount } \\
\text { of bleeding? }\end{array}$ & \multicolumn{2}{|c|}{$(n=199)$} \\
\hline Mild & 177 & 88.9 \\
\hline Moderate & 15 & 7.5 \\
\hline Severe & 4 & 2.0 \\
\hline Very severe & 3 & 1.5 \\
\hline $\begin{array}{l}\text { Q11. Did this bleeding } \\
\text { disappear after recovery? }\end{array}$ & \multicolumn{2}{|c|}{$(n=199)$} \\
\hline No & 104 & 52.3 \\
\hline Yes & 95 & 47.7 \\
\hline
\end{tabular}

Finally, the demographic data describing the relation between gingival bleeding and SARS-CoV-2 infection is presented in Table 3. It was noticed that gingival bleeding was more prevalent among females $(63.8 \% ; \mathrm{n}=127)$ compared to males (36.2\%; $\mathrm{n}=72$ ) (odds ratio, 0.859 [95\% CI, 0.530 - 1.394]). A statistically significant association was found among the age group of $31-40$ years $(28.6 \%$; $n=57)$ (odds ratio, 8.929 [95\% CI, 1.018 - 78.341]). Moreover, it was observed that gingival bleeding was more prevalent among patients who brushed twice a day during the phase of infection (47.2\%; $n=94$ ) (odds ratio, 0.952 [95\% CI, $0.570-1.592])$, and less frequent among flossers (32.7\%; n=65) (odds ratio, 1.044 [95\% CI, $0.642-1.698]$ ).

\section{Discussion}

SARS-CoV-2, a novel coronavirus, was initially discovered in late 2019 and has quickly grown to create a global pandemic. ${ }^{18}$ COVID-19 was first described in Wuhan, China and was designated a public health emergency in January 2020.1,3 It is characterized by a variety of clinical manifestations; in a typical case, a high fever appears following dry cough and in some cases, viral pneumonia develops and advances, resulting in shortness of breath. ${ }^{19}$ COVID-19 is notable for its capacity to generate an overactive immunological response in the host, known as a cytokine storm, which results in significant tissue destruction, notably in the connective tissue of the lungs. ${ }^{20}$

Several studies have pointed to the oral cavity as the primary source of SARSCoV-2 infection. SARS-CoV-2 expression has been found in the oral epithelium, phlegm, and swabs of human saliva. ${ }^{21,22,23}$ It is known that the oral cavity may exhibit manifestations of underlying diseases such as oral ulcerations, gingival bleeding, glossitis, oral pain, or halitosis. ${ }^{24,25}$ Oral tissue ulceration or blistering are the most common symptoms of viral infections. ${ }^{26}$ Recurrent mouth ulcers may be an early sign of COVID-19. According to a case report, an irregular ulcer on the dorsal side of the tongue of a 45-year-old female patient started as a painful inflammation of a tongue papilla and turned into an erythematous macula after 24 hours, which evolved into an irregular and asymptomatic ulcer preceding testing positive for COVID-19. ${ }^{10}$ Dry mouth and amblygeustia are two other predominant oral-related symptoms that 
were experienced by a very high proportion of COVID-19 patients, implying that oral symptoms can be considered as initial symptoms of COVID-19 infection. ${ }^{27}$ The first description of oral mucosal manifestations of COVID-19 was reported by Cebeci Kahraman and Çaşkurlu in 2020 and they stated that the mucosal lesions were not just small enanthema, but were composed of diffuse oropharyngeal erythema, petechia, and pustule formation suggesting that oral mucosal involvement should be kept in mind as a potential symptom of COVID-19. ${ }^{28}$

Table 3. Relation between gingival bleeding during time of virus infection and demographic data

\begin{tabular}{|c|c|c|c|c|c|c|c|c|}
\hline \multirow[t]{3}{*}{ Demographic Data } & \multicolumn{4}{|c|}{$\begin{array}{l}\text { Did you have gum bleeding } \\
\text { during time of virus } \\
\text { infection? }\end{array}$} & \multirow[t]{3}{*}{$\chi^{2}$} & \multirow[t]{3}{*}{$\mathbf{P}$} & \multirow[t]{3}{*}{ OR } & \multirow[t]{3}{*}{$\begin{array}{l}\text { 95\% CI } \\
\text { (LL - } \\
\text { UL) }\end{array}$} \\
\hline & \multicolumn{2}{|c|}{$\begin{array}{c}\text { No } \\
(\mathrm{n}=116)\end{array}$} & \multicolumn{2}{|c|}{$\begin{array}{c}\text { Yes } \\
(n=119)\end{array}$} & & & & \\
\hline & No. & $\%$ & No. & $\%$ & & & & \\
\hline \multicolumn{9}{|l|}{ Sex } \\
\hline Male & 38 & 32.8 & 72 & 36.2 & \multirow[t]{2}{*}{0.378} & \multirow[t]{2}{*}{0.539} & - & - \\
\hline Female & 78 & 67.2 & 127 & 63.8 & & & 0.859 & $\begin{array}{l}(0.530- \\
1.394)\end{array}$ \\
\hline \multicolumn{9}{|l|}{ Age } \\
\hline $18-30$ & 56 & 48.3 & 100 & 50.3 & \multirow[t]{5}{*}{5.760} & \multirow[t]{5}{*}{0.218} & - & - \\
\hline $31-40$ & 32 & 27.6 & 57 & 28.6 & & & $8.929^{*}$ & $\begin{array}{l}(1.018- \\
78.341)\end{array}$ \\
\hline $41-50$ & 17 & 14.7 & 29 & 14.6 & & & 8.906 & $\begin{array}{l}(0.997- \\
79.599)\end{array}$ \\
\hline $51-60$ & 6 & 5.2 & 12 & 6 & & & 8.529 & $\begin{array}{l}(0.918- \\
79.239)\end{array}$ \\
\hline $60+$ & 5 & 4.3 & 1 & 0.5 & & & 10.000 & $\begin{array}{l}(0.944- \\
105.921)\end{array}$ \\
\hline \multicolumn{9}{|l|}{$\begin{array}{l}\text { Q3. How many times } \\
\text { do you brush your } \\
\text { teeth daily? }\end{array}$} \\
\hline Once a day & 39 & 33.6 & 70 & 35.2 & \multirow[t]{5}{*}{2.955} & \multirow{5}{*}{$\begin{array}{l}{ }^{\mathrm{MC}} \mathrm{p}= \\
0.584\end{array}$} & - & - \\
\hline Twice a day & 55 & 47.4 & 94 & 47.2 & & & 0.952 & $\begin{array}{l}(0.570- \\
1.592)\end{array}$ \\
\hline Thrice a day & 18 & 15.5 & 23 & 11.6 & & & 0.712 & $\begin{array}{l}(0.343- \\
1.478)\end{array}$ \\
\hline $\begin{array}{l}\text { Less than } 3 \text { times } \\
\text { weekly }\end{array}$ & 4 & 3.4 & 8 & 4 & & & 1.114 & $\begin{array}{c}(0.315- \\
3.938)\end{array}$ \\
\hline $\begin{array}{l}\text { I rarely brush my } \\
\text { teeth. }\end{array}$ & o & o & 4 & 2 & & & - & - \\
\hline \multicolumn{9}{|l|}{$\begin{array}{l}\text { Q4. Do you use dental } \\
\text { floss? }\end{array}$} \\
\hline No & 77 & 66.4 & 134 & 67.3 & \multirow[t]{2}{*}{0.030} & \multirow[t]{2}{*}{0.862} & - & - \\
\hline Yes & 39 & 33.6 & 65 & 32.7 & & & 1.044 & $\begin{array}{c}(0.642- \\
1.698)\end{array}$ \\
\hline
\end{tabular}

$\chi^{2}$ : Chi-square test; MC: Monte Carlo; *: statistically significant at P $\leq 0.05$; OR: odds ratio; CI: confidence interval; LL: lower limit; UL: upper limit

Furthermore, COVID-19 patients seem to be prone to coagulation dysfunction with signs of small blood vessel occlusion, as is evident by systemic, as well as cutaneous findings of ischemia in the limbs. These microcirculation disorders and cutaneous manifestations that patients with COVID-19 may develop can clinically present as 
findings that range from petechiae or tiny bruises, to nonpruritic blanching livedoid vascular eruptions on extremities, to plantar plaques, plantar vesicles, dry gangrene, or just bruising in the fingers and toes. ${ }^{29}$ Kalner and Vergilis also reported that the appearance of periorbital dyschromia may serve as an early cutaneous manifestation of COVID-19 and as a precursor for the systemic symptoms that seem to follow this presentation. ${ }^{30}$

Besides viral invasion, it was speculated that oral symptoms may also be due to the patient's change in psychological status, poor oral hygiene, or microbiota imbalance caused by therapeutic drugs. High ACE2 expression in particular, can be found on the epithelial cells of the oral mucosa, which is enriched in epithelial cells of the tongue, thus providing possible routes of entry for SARS-CoV-2. ${ }^{21}$ Therefore, the oral mucosa might be at potential risk of infection by SARS-CoV-2, suggesting that oral symptoms could also be considered as initial symptoms of COVID-19, which might be new diagnostic criteria. At the same time, physicians should pay more attention to the oral condition and oral hygiene of patients and administer proper oral treatment or refer patients for dental care during the clinical treatment process. ${ }^{27}$

Recently, oral health has been shown to have a significant impact on overall health, as several studies have suggested that cytokines or microbial products released systemically in response to oral infection promote inflammation in distant organs, increasing the risk of systemic disorders such as Alzheimer's disease, diabetes, atherosclerotic heart disease, and cerebrovascular disease. Furthermore, poor dental health has been linked to the development of complications in systemic disorders such as diabetes, chronic kidney disease, and liver disease according to research. ${ }^{31-36}$

Recent research has suggested a link between periodontal disease and COVID-19. Its severity and progression may be influenced by the inflammatory response that occurs during periodontitis.37-39 Furthermore, some investigations have suggested that this theory is the result of bacterial superinfection in the oral cavity. Periodontitis and COVID-19 problems may be linked by bacterial infections invading the gingival epithelium through ulceration.39-41 Cytokine profiles in periodontal diseases have been studied and assessed and it has been indicated that in gingivitis, patients had noticeably higher IL-1ß and lower IL-8 concentrations at later stages of the disease..$^{2}$ COVID-19 and periodontitis have a high degree of similarity in the serum level change of key cytokine profiles, implying that there may be a link between the two diseases. Furthermore, because gene polymorphisms in cytokine-related genes such as IL-1 $\alpha$, IL-1ß, IL-6, IL-10, TNF- $\alpha$, and INFY affect periodontal disease, it is probable that they also affect COVID-19.43 Other researchers have hypothesized that during SARS-CoV-2 infection, periodontal disease could be aggravated due to the down regulation of ACE2 and an increase in ACE and angiotensin II, thereby resulting in the involvement of several pro-inflammatory factors. Their studies have shown that due to the renin-angiotensin system in periodontal sites, ACE2 might play a fundamental role in the under- or overexpression of cytokines associated with periodontal disease, such as IL-6, IL-7, TNF- $\alpha$, IL-2, IL-1 $\beta$, monocyte chemoattractant protein (MCP)-1, and transforming growth factor (TGF)- $\beta$, mainly during coinfection with SARS-CoV-2, where ACE2 is underexpressed rendering patients unresponsive to inflammatory processes and facilitating periodontal loss. 44,45

Asymptomatic COVID-19 patients may present for emergency dental treatment. These patients are expected to have saliva contaminated with the virus and they are a confirmed source of infection. ${ }^{46}$ Moreover, the conjunctival mucosa and upper respiratory tract are connected by the nasolacrimal duct, and since they share ACE2 on their cell membrane, dental healthcare personnel are at risk of infection via direct exposure of the conjunctiva to droplets from patients during dental treatment. 15,46

The limitations of this study include not using a larger sample size and neglecting the investigation of moderate and severe hospitalized cases of the disease, both of which could help elucidate the actual 
association. Furthermore, since this was a retrospective study, it was unfeasible to control oral hygiene measures during the infection stage.

Based on our findings, it can be concluded that gingival bleeding may be considered a COVID-19 introductory sign and is a prevalent symptom as reported by infected patients. However, COVID-19 is a non-binary respiratory infection and it is well established now that there is a dose dependent relation between the viral load and signs of the disease. Gingival bleeding may be subject to the same dependency. During the pandemic, we recommend that dentists and periodontists take this symptom, as well as any other oral signs that may be linked to COVID-19, into consideration when screening new patients, who may be asymptomatic carriers of the disease or in the prodromal phase of infection. Additionally, proper universal infection control protocols and guidelines must be strictly abided by to protect dental practitioners worldwide.

\section{References}

1. Zhang YZ, Holmes EC. A Genomic Perspective on the Origin and Emergence of SARS-CoV-2. Cell. 2020 Apr 16; 181(2):223-227.

https://doi.org/10.1016/j.cell.2020.03.0 35

2. Li R, Pei S, Chen Bi, et al. Substantial undocumented infection facilitates the rapid dissemination of novel coronavirus (SARS-CoV-2). Science. 2020 May 1; 368(6490):489-493. https://doi.org/10.1126/science.abb322 1

3. Zheng J. SARS-CoV-2: an Emerging Coronavirus that Causes a Global Threat. Int J Biol Sci. 2020 Mar 15; 16(10):16781685 .

https://doi.org/10.7150/ijbs.45053

4. Casillas Santana MA, Arreguín Cano JA, Dib Kanán A, et al. Should We Be Concerned about the Association of Diabetes Mellitus and Periodontal Disease in the Risk of Infection by SARSCoV-2? A Systematic Review and Hypothesis. Medicina. 2021; 57(5):493508. https://doi.org/10.3390/medicina5705 0493

5. Zhang R, Wang X, Ni L, et al. COVID-19: Melatonin as a potential adjuvant treatment. Life Sci. 2020 Jun 1; 250:117583.

https://doi.org/10.1016/j.lfs.2020.11758 3

6. Law HK, Cheung $\mathrm{CY}, \mathrm{Ng} \mathrm{HY}$, et al. Chemokine up-regulation in SARScoronavirus-infected, monocyte-derived human dendritic cells. Blood. 2005 Oct 1; 106(7):2366-2374.

https://doi.org/10.1182/blood-2004-104166

7. Chu H, Zhou J, Wong BH, et al. Middle East Respiratory Syndrome Coronavirus Efficiently Infects Human Primary $T$ Lymphocytes and Activates the Extrinsic and Intrinsic Apoptosis Pathways. $J$ Infect Dis. 2016 Mar 15; 213(6):904-914. https://doi.org/10.1093/infdis/jiv380

8. Xu J, Li Y, Gan F, Du Y, Yao Y. Salivary Glands: Potential Reservoirs for COVID19 Asymptomatic Infection. $J$ Dent Res. 2020 Jul; 99(8):989. https://doi.org/10.1177/002203452091 8518

9. Pedrosa MS, Sipert, CR, Nogueira FN. Salivary Glands, Saliva and Oral Findings in COVID-19 infection. Pesqui Bras Odontopediatria Clín Integr. 2020; 20(suppl 1):e0104. https://doi.org/10.1590/pboci.2020.112 10. Chaux-Bodard A, Deneuve S, Desoutter A. Oral manifestation of Covid-19 as an inaugural symptom? J Oral Med Oral Surg. $\quad 2020 \quad$ Apr; $26(2): 18$. https://doi.org/10.1051/mbcb/2020011

11. Martín Carreras-Presas C, Amaro Sánchez J, López-Sánchez AF, JanéSalas E, Somacarrera Pérez ML. Oral vesiculobullous lesions associated with SARS-CoV-2 infection. Oral Dis. 2021 Apr; $27 \quad$ Suppl 3:710-712. https://doi.org/10.1111/odi.13382

12. Manzalawi R, Alhmamey K, Abdelrasoul M. Gingival bleeding associated with COVID-19 infection. Clin Case Rep. 2021 Jan; 9(1):294-297. https://doi.org/10.1002/ccr3.3519

13. Amorim Dos Santos J, Normando AGC, Carvalho da Silva RL, et al. Oral mucosal lesions in a COVID-19 patient: New signs or secondary manifestations? Int J Infect 
Dis. $2020 \quad$ Aug; 97:326-328. https://doi.org/10.1016/j.ijid.2020.06.0 12

14. Marouf N, Cai W, Said KN, et al. Association between periodontitis and severity of COVID-19 infection: A casecontrol study. J Clin Periodontol. 2021 Apr; 48(4):483-491. https://doi.org/10.1111/jcpe.13435

15. Liu Z, Sun CB. Conjunctiva is not a preferred gateway of entry for SARS$\mathrm{CoV}-2$ to infect respiratory tract. $J$ Med Virol. 2020 Sep; 92(9):1410-1412. https://doi.org/10.1002/jmv.25859

16. Odeh ND, Babkair H, Abu-Hammad S, Borzangy S, Abu-Hammad A, AbuHammad O. COVID-19: Present and Future Challenges for Dental Practice. Int $J$ Environ Res Public Health. 2020 Apr 30; 17(9):3151. https://doi.org/10.3390/ijerph17093151

17. Chen N, Zhou M, Dong X, et al. Epidemiological and clinical characteristics of 99 cases of 2019 novel coronavirus pneumonia in Wuhan, China: a descriptive study. Lancet. 2020 Feb 15; 395(10223):507-513. https://doi.org/10.1016/So1406736(20)30211-7

18. Liu YC, Kuo RL, Shih SR. COVID-19: The first documented coronavirus pandemic in history. Biomed J. 2020 Aug; 43(4):328-333.

https://doi.org/10.1016/j.bj.2020.04.00 7

19. Yang $\mathrm{X}, \mathrm{Yu} \mathrm{Y}, \mathrm{Xu}$ J, et al. Clinical course and outcomes of critically ill patients with SARS-CoV-2 pneumonia in Wuhan, China: a single-centered, retrospective, observational study. Lancet Respir Med. $2020 \quad$ May; 8(5):475-481. https://doi.org/10.1016/S22132600(20)30079-5

20.Pedersen SF, Ho YC. SARS-CoV-2: a storm is raging. $J$ Clin Invest. 2020 May 1; $\quad$ 130(5):2202-2205. https://doi.org/10.1172/JCI137647

21. Xu H, Zhong L, Deng J, et al. High expression of ACE2 receptor of 2019$\mathrm{nCoV}$ on the epithelial cells of oral mucosa. Int $J$ Oral Sci. 2020 Feb 24; 12:8. https://doi.org/10.1038/s41368020-0074-x

22. To KK, Tsang OT, Leung WS, et al. Temporal profiles of viral load in posterior oropharyngeal saliva samples and serum antibody responses during infection by SARS-CoV-2: an observational cohort study. Lancet Infect Dis. $2020 \quad$ May; 20(5):565-574. https://doi.org/10.1016/S14733099(20)30196-1

23. Zhang W, Du RH, Li B, et al. Molecular and serological investigation of 2019$\mathrm{nCoV}$ infected patients: implication of multiple shedding routes. Emerg Microbes Infect. 2020 Feb 17; 9(1):386389.

https://doi.org/10.1080/22221751.2020 .1729071

24. Gaddey HL. Oral manifestations of systemic disease. Gen Dent. 2017 NovDec; 65(6):23-29.

25. Santosh ABR, Muddana K. Viral infections of oral cavity. $J$ Family Med Prim Care. 2020 Jan; 9(1):36-42. https://doi.org/10.4103/jfmpc.jfmpc_8 07_19

26. Pedrosa M, de Paiva M, Oliveira L, Pereira S, da Silva C, Pompeu J. Oral manifestations related to dengue fever: a systematic review of the literature. Aust Dent J. 2017 Dec; 62(4):404-11. https://doi.org/10.1111/adj.12516

27. Chen L, Zhao J, Peng J, et al. Detection of SARS-CoV-2 in saliva and characterization of oral symptoms in COVID-19 patients. Cell Prolif. 2020 Dec; 53(12):e12923. https://doi.org/10.1111/cpr.12923

28. Cebeci Kahraman F, Çaşkurlu H. Mucosal involvement in a COVID-19positive patient: A case report. Dermatol Ther. $2020 \quad J u l ; \quad 33(4): \mathrm{e} 13797$. https://doi.org/10.1111/dth.13797

29.Zhang Y, Xiao M, Zhang S, et al. Coagulopathy and Antiphospholipid Antibodies in Patients with Covid-19. $N$ Engl $J$ Med. 2020 Apr; 382(17):e38. https://doi.org/10.1056/NEJMc200757 5

30.Kalner S, Vergilis IJ. Periorbital erythema as a presenting sign of COVID19. JAAD Case Rep. 2020 Oct; 6(10):996-998.

https://doi.org/10.1016/j.jdcr.2020.05. 001

31. Bui FQ, Almeida-da-Silva CLC, Huynh B, et al. Association between periodontal pathogens and systemic disease. Biomed 
J. $2019 \quad$ Feb; 42(1):27-35. https://doi.org/10.1016/j.bj.2018.12.00 1

32. Wu Z, Nakanishi H. Connection between periodontitis and Alzheimer's disease: possible roles of microglia and leptomeningeal cells. $J$ Pharmacol Sci. 2014; 126(1):8-13. https://doi.org/10.1254/jphs.14r11cp

33. Jepsen S, Stadlinger B, Terheyden H, Sanz M. Science transfer: oral health and general health - the links between periodontitis, atherosclerosis and diabetes. J Clin Periodontol. 2015 Dec; 42(12):1071-1073.

https://doi.org/10.1111/jcpe.12484

34. Khumaedi AI, Purnamasari D, Wijaya IP, Soeroso Y. The relationship of diabetes, periodontitis and cardiovascular disease. Diabetes Metab Syndr. 2019 Mar-Apr; 13(2):1675-1678. https://doi.org/10.1016/j.dsx.2019.03.0 23

35. Ghezzi EM, Ship JA. Systemic diseases and their treatments in the elderly: impact on oral health. $J$ Public Health Dent. 2000 Fall; 60(4):289-296. https://doi.org/10.1111/j.17527325.2000.tbo3337.x

36. Han P, Sun D, Yang J. Interaction between periodontitis and liver diseases. Biomed Rep. 2016 Sep; 5(3):267-276. https://doi.org/10.3892/br.2016.718

37. Pitones-Rubio V, Chávez-Cortez EG, Hurtado-Camarena A, González-Rascón A, Serafín-Higuera N. Is periodontal disease a risk factor for severe COVID-19 illness? Med Hypotheses. 2020 Nov; 144:109969.

https://doi.org/10.1016/j.mehy.2020.10 9969

38. Cardoso EM, Reis C, ManzanaresCéspedes MC. Chronic periodontitis, inflammatory cytokines, and interrelationship with other chronic diseases. Postgrad Med. 2018 Jan; 130(1):98-104.

https://doi.org/10.1080/00325481.201 8.1396876

39. Räisänen IT, Umeizudike KA, Pärnänen $\mathrm{P}$, et al. Periodontal disease and targeted prevention using aMMP-8 point-of-care oral fluid analytics in the COVID-19 era. Med Hypotheses. 2020 Nov; 144:110276. https://doi.org/10.1016/j.mehy.2020.11 0276

40.Herrera D, Serrano J, Roldán S, Sanz M. Is the oral cavity relevant in SARS-CoV-2 pandemic? Clin Oral Investig. 2020 Aug; 24(8):2925-2930.

https://doi.org/10.1007/s00784-02003413-2

41. Patel J, Sampson V. The role of oral bacteria in COVID-19. Lancet Microbe. 2020 Jul; 1(3):e105. https://doi.org/10.1016/S26665247(20)30057-4

42. Deinzer R, Weik U, Kolb Bachofen V, Herforth A. Comparison of experimental gingivitis with persistent gingivitis: differences in clinical parameters and cytokine concentrations. $J$ Periodontal Res. 2007 Aug; 42(4):318-324. https://doi.org/10.1111/j.16000765.2006.00951.x

43. Hajizadeh F, Houshmand B, Ekhlasmandkermani M, Khazaei S, Kheiri A. Cytokine Profiles in Periodontitis and COVID-19. Dent Hypotheses. 2021 Mar; 12(1):36-38. https://doi.org/10.4103/denthyp.denth yp_161_20

44. Mancini L, Quinzi V, Mummolo S, Marzo G, Marchetti E. Angiotensin-Converting Enzyme 2 as a Possible Correlation between COVID-19 and Periodontal Disease. Appl Sci. 2020 Sep; 10(18):6224.

https://doi.org/10.3390/app10186224

45. Silhol F, Sarlon G, Deharo JC, Vaïsse B. Downregulation of ACE2 induces overstimulation of the renin-angiotensin system in COVID-19: should we block the renin-angiotensin system? Hypertens Res. 2020 Aug; 43(8):854-856. https://doi.org/10.1038/s41440-0200476-3

46. Odeh ND, Babkair H, Abu-Hammad S, Borzangy S, Abu-Hammad A, AbuHammad O. COVID-19: Present and Future Challenges for Dental Practice. Int $J$ Environ Res Public Health. 2020 Apr 30; 17(9):3151. https://doi.org/10.3390/ijerph17093151

Conflicts of interest: The authors declared no conflicts of interest related to this work. 


\section{Corresponding author:}

Dr. Mohamed Roshdy Abdelrasoul

Lecturer of Periodontics, Periodontology

Division

Dentistry Program

Batterjee Medical College

Jeddah, Kingdom of Saudi Arabia
E-mail: dental14.jed@bmc.edu.sa

Phone: +20 1003508225 -

+966582570773

This is an open access article distributed under the Creative Commons AttributionNoncommercial-NoDerivatives 4.0 International (CC BY-NC-ND 4.0) License. 